\title{
Diversified analysis of renewable energy contribution for energy supply
} in Asian regions

\author{
Genku Kayo ${ }^{1, *}$, Takashi Ikegami ${ }^{2}$, Tomoki Ehara ${ }^{3}$, Kazuyo Oyamada ${ }^{3}$, \\ Shuichi Ashina ${ }^{1}$, Junichi Fujino ${ }^{1}$ \\ ${ }^{1}$ National Institute for Environmental Studies (NIES), Ibaraki, Japan \\ ${ }^{2}$ Institute of Industrial Science (IIS), Tokyo, Japan \\ ${ }^{3}$ Mizuho Information and Research Institute (MHIR), Tokyo, Japan \\ *Corresponding author. Tel: +81-29-850-2019, Fax: +81-29-850-2422, E-mail:kayo.genku@nies.go.jp
}

\begin{abstract}
Renewable energy is one of the key drivers for reducing $\mathrm{CO}_{2}$ emissions in the future. In order to support effective policy-making relating to renewable energy, estimation of available potentials mixed with all energy resources including fossil fuels is needed. However, previous research has sometimes focused on only one particular approach. Therefore, a diversified analysis of potential renewable energy contributions to energy supply in Asian regions was carried out in this paper. In order to estimate physical potential, a grid cell approach using geographical information system (GIS) data was adopted. Once the physical and technical potential had been estimated, the economic potential was then calculated. Socio-economic potential was analyzed using energy outlook data collected and reviewed from various publications in order to assess trends in energy demand and supply. The results indicate that almost all Asian countries will continue to develop and that the demand for energy will grow. With the aspect from potential amount, renewable energy supply is effective even though fossil fuels will continue to dominate totally energy mixes for the foreseeable future. In renewable energy supply, potential of solar is dominated and bears on wide implication compared with that of wind and biomass. To ensure the best possible results, further research should be carried out on the optimal schedule for the multiphased introduction of renewable energy in long-term policy.
\end{abstract}

Keywords: Solar energy potential, Wind energy potential, Biomass energy potential, Asian region

\section{Introduction}

Renewable energy is one of the key drivers for reducing $\mathrm{CO}_{2}$ emissions in the future. The third annual report (TAR) compiled by the IPCC expresses the relative potential of several phases of renewable energy in terms of physical, technological, socio-economic, economic and market potentials. In order to support effective policy-making relating to renewable energy, estimation of available potentials mixed with all energy resources including fossil fuels is needed. However, previous researches have sometimes focused on only one particular resource, for instance, solar energy (Hofman et al., 2002), wind energy (Grubb and Meyer, 1993) and biomass energy (Berndes et al., 2003). In this paper, diversified analysis of renewable energy contributions was carried out considering energy mix with fossil fuels and trends of energy demand. Renewable energy potentials were estimated in ten Asian regions. These regions included Japan (JPN), China (CHN), India (IND), Indonesia (IDN), Korea (KOR), Thailand (THA), Malaysia (MYS), Viet Nam (VNM), the Philippines (PHL) and Singapore (SGP).

\subsection{Renewable energies}

In this paper, three renewable energy sources were selected for investigation: solar, wind and biomass energy. It is expected that technologies to make use of these energy sources will be introduced into Asian countries in order to create a decentralized energy generation and supply system. Solar energy is included in this paper only in terms of the electricity generation provided by photovoltaic (PV) cells. 


\subsection{Definition}

According to TAR (IPCC, 2001a), renewable energy can be described in terms of the following "potentials". The physical potential of a renewable energy source is the amount of that resource theoretically available in the area in question, and which can be considered suitable for production. This includes any constraints imposed by land use considerations or local site characteristics such as elevation and slope. The technical potential of a renewable energy source is the part of physical potential remaining after all losses due to conversion from the extractable primary energy source to secondary energy carriers or other forms of energy (electricity, fuel etc.) are taken into account. The socio-economic potential of a renewable energy source is the actual capacity for renewable energy use, taking into consideration the distribution of energy mixes and the growth of primary energy demand. The economic potential of a renewable energy source is the technical potential, based on the estimated production cost of a secondary form of energy which is competitive with a specified, locally relevant alternative. A flexible way to represent the economic potential is, therefore, in the form of energy production potential, expressed as a function of the production cost.

\section{Methodology}

\subsection{Estimation of physical and technological potential}

\subsubsection{Data collection}

In order to estimate physical potential, a grid cell approach using geographical information system (GIS) data was adopted. The physical potentials were estimated on a global basis using previously collected data such as insolation and wind speed measurements, land cover, elevation and wilderness area data. After calculation of the optimal inclination angle for solar PV cells in each grid cell, the total amounts of generation were estimated per cell and aggregated on a country-by-country basis. Table 1 shows the GIS data list that was used in this estimation process. (All the data used has been published on websites and made available for simulation purposes $[5,6,7,8,9,10,11])$.

Table 1. Data sources

\begin{tabular}{cll}
\hline Category & \multicolumn{1}{c}{ Data source } & \multicolumn{1}{c}{ Original data provider } \\
\hline Land cover & $\begin{array}{l}\text { MODIS/Terra Land Cover Type Yearly L3 } \\
\text { Global 1km, Land Cover Type 1 (IGBP), 2005 }\end{array}$ & $\begin{array}{l}\text { NASA Land Processes } \\
\text { Distributed Active Archive } \\
\text { Center }\end{array}$ \\
\hline Elevation & $\begin{array}{l}\text { The Global Land One-km Base Elevation } \\
\text { (GLOBE) Data, 1999 }\end{array}$ & $\begin{array}{l}\text { National Geophysical Data } \\
\text { Center }\end{array}$ \\
\hline Bathymetry & GEBCO One Minute Grid Version 2.00, 2006 & $\begin{array}{l}\text { General Bathymetric Chart } \\
\text { of the Oceans }\end{array}$ \\
\hline Wilderness & World Wilderness Areas, 1993 & UNEP/GRID \\
\hline \multirow{2}{*}{ Insolation } & $\begin{array}{l}\text { Surface Meteorology and Solar Energy Release } \\
\text { 6.0 Data Set; Monthly averaged insolation } \\
\text { incident on a horizontal surface, 2008 }\end{array}$ & $\begin{array}{l}\text { NASA Langley Research } \\
\text { Center, Atmospheric } \\
\text { Science Data Center }\end{array}$ \\
\hline \multirow{2}{*}{ Wind Speed } & $\begin{array}{l}\text { Surface Meteorology and Solar Energy Release } \\
\text { 5.0 Data Set; Monthly averaged wind speed at } \\
\text { 50m above the surface, 2005 }\end{array}$ & \\
\hline
\end{tabular}




\subsubsection{Solar energy potential}

Monthly and hourly solar energy potential in 3-by-3 arc-minute grid cells was calculated from averaged insolation data, averaged wind speed data, land cover type data, and so on. Compared with the previous method used (Bert. J. M. de Vries, 2007), extra parameters were included in the form of solar elevation angle, solar azimuth angle, land surface slope and elevation angle. In addition, the optimum inclination angle of each solar PV cell was calculated per grid cell and this information was also taken into account. The inclusion of these factors allowed a more accurate estimation to be made of the solar energy potential. The available area was determined using a suitability fraction, as shown in Table 2. For technical reasons, the area studied was limited to less than $5000 \mathrm{~m}$ elevation and less than $60 \%$ slope. Solar energy potential, EPS [kWh/yr], was calculated using Eq. (1).

$$
E P S_{g}=\sum_{M, T} I_{g, M, T} \cdot A_{g} \cdot \frac{e}{100}
$$

where $I$ is the insolation intensity at the optimum inclination angle of solar PV $\left[\mathrm{kW} / \mathrm{m}^{2}\right], A$ is the PV cell area $\left[\mathrm{m}^{2}\right]$, and $e$ is the PV module efficiency (=13\%). The subscripts $g, M$ and $T$ stand for the grid cell, month and time, respectively.

\subsubsection{Wind energy potential}

The wind turbine was assumed to be $80 \mathrm{~m}$ high with a capacity of $2 \mathrm{MW}$ and rotors $90 \mathrm{~m}$ in diameter. The available area was determined using a suitability fraction, as shown in Table 2, and restricted to less than $2000 \mathrm{~m}$ elevation and less than $60 \%$ slope. Since the reference wind measurements provided by the surface meteorology dataset (NASA, 2005) were for a height of $50 \mathrm{~m}$, averaged wind speed was adjusted to a height of $80 \mathrm{~m}$, equal to that of the wind turbine. When the wind energy potential, $E P W[\mathrm{kWh} / \mathrm{yr}]$, was calculated the probability distribution of wind speed $v[\mathrm{~m} / \mathrm{s}]$, the wind power correction factor $k$, and the availability rate $\mathrm{j}[\%]$ were also taken into account, as shown in Eq. (2).

$$
E P W_{g}=\sum_{v, L C} P(v) \cdot R(v) \cdot 8760 \cdot j \cdot k_{L C} \cdot(1-l) \cdot N w_{g \cdot L C}
$$

where $l$ is the loss rate, $L C$ is the land cover, $P(v)[\mathrm{kW}]$ is the output of the wind turbine when the wind speed is $v[\mathrm{~m} / \mathrm{s}]$, and $R(v)$ refers to the appearance probability distribution of the wind speed $v[\mathrm{~m} / \mathrm{s}]$. Table 2 shows the parameter values for each type of land cover. Seventeen land cover categories were consolidated into four land use patterns. The suitability fraction values were one of the effective factors used in this estimation method. Therefore, in future, adequate suitability fractions should be estimated and modified by comparison with other, more precise calculations.

\begin{tabular}{|c|c|c|c|}
\hline \multirow[t]{2}{*}{ Land cover } & \multicolumn{2}{|c|}{$\begin{array}{l}\text { Suitability } \\
\text { Fraction [\%] }\end{array}$} & \multirow{2}{*}{$\begin{array}{c}\text { Power } \\
\text { Correction } \\
\text { Factor [\%] }\end{array}$} \\
\hline & Solar & Wind & \\
\hline $\begin{array}{l}\text { All Forest, Closed Shrublands, Woody Savannas, Permanent } \\
\text { Wetlands, Snow and Ice, Water Bodies }\end{array}$ & 0 & 0 & 90 \\
\hline Urban and Built-Up Areas & 1 & 0 & 90 \\
\hline Croplands, Natural Vegetation Mosaic & 0 & 30 & 90 \\
\hline $\begin{array}{l}\text { Open Shrublands, Savannas, Grasslands, Barren or Sparsely } \\
\text { Vegetated Areas }\end{array}$ & 1 & 50 & 95 \\
\hline
\end{tabular}

Table 2. Parameter values for each type of land cover 


\subsubsection{Biomass energy potential}

In the biomass energy potential calculation, twelve different resources (provided by the FAO statistical report, FAOSTAT, FAO, 2001) were taken into account. These resources included industrial round wood residues, pulp used for paper, sawn wood, mill residues, paper scrap, timber scrap, crop residues, sugarcane residues, bagasse, dung, kitchen refuse, and human feces. Each resource was assigned a different residual rate - defined as the fraction of the total amount available in production and able to be used for production purposes. Statistical data were, therefore, prepared in terms of volume or weight. The residual volumes were then converted to calorific values for calculation purposes.

\subsubsection{Renewable energy potential grades}

Renewable energy potentials were calculated and classified into three grades. When physical potentials were calculated, each grid cell was classified in terms of its renewable resource advantage. Grade I had some specific advantage in terms of its use as a renewable energy source, while grade III had some specific disadvantage associated with its use, due to location or climatic conditions. In the case of solar energy, the grade was determined by the insolation intensity received by each solar PV module $\left[\mathrm{kWh} / \mathrm{m}^{2} / \mathrm{yr}\right]$. In the case of wind energy, the grade was determined by the utility operation rate, UC [\%], defined by the percentage of annual electricity [TWh/yr] generated by full load operation throughout the year. The classified grades are shown in Table3 and 4.

\subsection{Socio-economic potential estimation}

Many institutes have published reports presenting statistical data or perspectives concerning the future of the Asian region, and this information is essential in order to estimate the contribution of renewable energies. However, because the Asian region is growing so rapidly and so dramatically, it is difficult to accurately construct future scenarios. Some reports published by international institutes (IPCC, 2001; IEA, 2009; EUROPEAN COMMISION, 2006; ADB, 2009; Greenpeace, 2008; Shell, 2008; Energy Research Institute, 2009; OECD, 2008 and so on) present various possible energy outlooks for future scenarios. Consequently, in this study, data relating to energy outlook were collected and reviewed in order to estimate expected trends in energy demand, supply and energy share in each country. After collecting data on the relevant parameters, maximum and minimum values were selected and a range of growth rates were established.

\subsection{Economic potential estimation}

After the calculations for physical and technical potential were completed, the production cost in each grid cell, $g$, was determined for each energy generation system. The production costs of solar energy, CS [USD/kWh], and wind energy, CW [USD/kWh], were calculated using Eq. (3) and Eq. (4).

$$
\begin{aligned}
& C S_{g}=\frac{r}{1-(1+r)^{-L S}} \cdot \frac{(1+O M) \cdot I N V S \cdot A_{g}}{E P S_{g}} \\
& C W_{g}=\frac{r}{1-(1+r)^{-L W}} \cdot \frac{(1+O M) \cdot I N V W \cdot A_{g}}{E P W_{g}}
\end{aligned}
$$

where $O M$ is the operation and maintenance cost expressed as a fraction of the investment cost, $r$ is the discount rate, and $L S$ or $L W$ is the durable period. EPS and EPW are the energy potentials calculated using Eq. (1) or Eq. (2). INVS and INVW represent the cost of the system. In the case of solar energy, INVS was set at $780\left[\mathrm{USD} / \mathrm{m}^{2}\right]$, which assumes 6 [USD/Wp] 
included per PV module and BOS. A represents the area of the PV cell $\left[\mathrm{m}^{2}\right]$. On the other hand, in the case of wind power, INVW was set at $760[\mathrm{USD} / \mathrm{kW}]$, and $A$ represents the construction area in each grid cell.

\section{Results}

\subsection{Physical and technical potentials}

\subsubsection{Potential grades}

Table 3 and 4 show the calculated results for physical and technical potential, broken down by grade. Comparing the three renewable energies studied shows that the solar energy potential is the largest, especially in grade II. China, India and Indonesia have some potential in grade I, reflecting good insolation conditions. However, regions such as Japan, China, Indonesia, Korea and Malaysia have more potential in grade III, overall, than in grade II. Wind energy potential is not as large as that of solar energy. Only China possesses significant potential in grade I. However, in the case of biomass energy, both China and India possess large potentials because of their large population and large plantation area. This physical potential analysis confirms that some countries have suitable renewable energy resources.

Table 3. Physical and technical potential, by grade (Solar Energy and Wind Energy)

\begin{tabular}{|c|c|c|c|c|c|c|c|c|}
\hline \multirow[b]{2}{*}{$\begin{array}{l}\text { Country } \\
\text { code }\end{array}$} & \multicolumn{3}{|c|}{ Solar Energy Potential [TWh/yr] } & \multicolumn{5}{|c|}{ Wind Energy Potential [TWh/yr] } \\
\hline & $\begin{array}{c}\text { Grade I } \\
2200-2600 \\
{\left[\mathrm{kWh} / \mathrm{m}^{2} / \mathrm{y}\right.} \\
]\end{array}$ & $\begin{array}{c}\text { Grade II } \\
1800-2200 \\
{\left[\mathrm{kWh} / \mathrm{m}^{2} / \mathrm{y}\right.} \\
]\end{array}$ & $\begin{array}{c}\text { Grade III } \\
0-1800 \\
{\left[\mathrm{kWh} / \mathrm{m}^{2} / \mathrm{y}\right.} \\
]\end{array}$ & Total & $\begin{array}{c}\text { Grade I } \\
40-100 \\
\text { [\%] }\end{array}$ & $\begin{array}{c}\text { Grade II } \\
30-40 \\
\text { [\%] }\end{array}$ & $\begin{array}{c}\text { Grade III } \\
0-30 \\
\text { [\%] }\end{array}$ & Total \\
\hline JPN & 0 & 465 & 39,692 & 40,157 & 0 & 38 & 26 & 64 \\
\hline $\mathrm{CHN}$ & 434 & 32,845 & 45,610 & 78,889 & 337 & 1,925 & 3,318 & 5,580 \\
\hline IND & 4,255 & 46,136 & 169 & 50,560 & 0 & 177 & 721 & 898 \\
\hline IDN & 5 & 1,625 & 3,699 & 5,329 & 0 & 0 & 45 & 45 \\
\hline KOR & 0 & 3,759 & 6,604 & 10,363 & 0 & 0 & 17 & 17 \\
\hline THA & 0 & 10,322 & 881 & 11,203 & 0 & 0 & 38 & 38 \\
\hline MYS & 0 & 1,243 & 2,361 & 3,604 & 0 & 0 & 5 & 5 \\
\hline VNM & 0 & 1,278 & 535 & 1,813 & 0 & 3 & 60 & 63 \\
\hline PHL & 0 & 1,304 & 9 & 1,313 & 0 & 0 & 42 & 42 \\
\hline SGP & 0 & 1,180 & 776 & 1,956 & 0 & 4 & 88 & 92 \\
\hline
\end{tabular}

Table 4. Physical and technical potential, by grade (Biomass Energy)

\begin{tabular}{lrrrr}
\hline \multirow{2}{*}{$\begin{array}{c}\text { Country } \\
\text { code }\end{array}$} & \multicolumn{6}{c}{ Biomass Energy Potential [TWh/yr] } \\
\cline { 2 - 5 } & Grade I & \multicolumn{1}{c}{ Grade II } & Grade III & \multicolumn{1}{c}{ Total } \\
\hline JPN & 109 & 15 & 15 & 139 \\
\hline CHN & 735 & 51 & 51 & 837 \\
\hline IND & 577 & 8 & 8 & 593 \\
\hline IDN & 121 & 7 & 7 & 135 \\
\hline KOR & 25 & 3 & 3 & 31 \\
\hline THA & 79 & 1 & 1 & 80 \\
\hline MYS & 47 & 1 & 1 & 48 \\
\hline VNM & 19 & 5 & 5 & 29 \\
\hline PHL & 39 & 1 & 1 & 40 \\
\hline SGP & 1 & 0 & 0 & 1 \\
\hline
\end{tabular}




\subsection{Socio-economic potentials}

\subsubsection{Review of expected energy demand in Asia}

Fig. 1 shows expected total primary energy demand throughout Asia, as reported by IPCC (SRES2001, IPCC, 2001b). The curved lines indicate the forecasts simulated by several different models. The predicted maximum value in 2050 is approximately 3.84 times larger than the minimum value in 2050. The calculated results for physical and technical potentials are represented by the horizontal dashed lines in Fig. 1 . The solar energy potentials, alone, can be seen to be large enough to meet the primary energy demand in all future scenarios. Wind energy potentials can also be seen to constitute an effective energy source. On the other hand, the biomass energy calculation shows that it is not large enough to constitute a major energy supply resource.

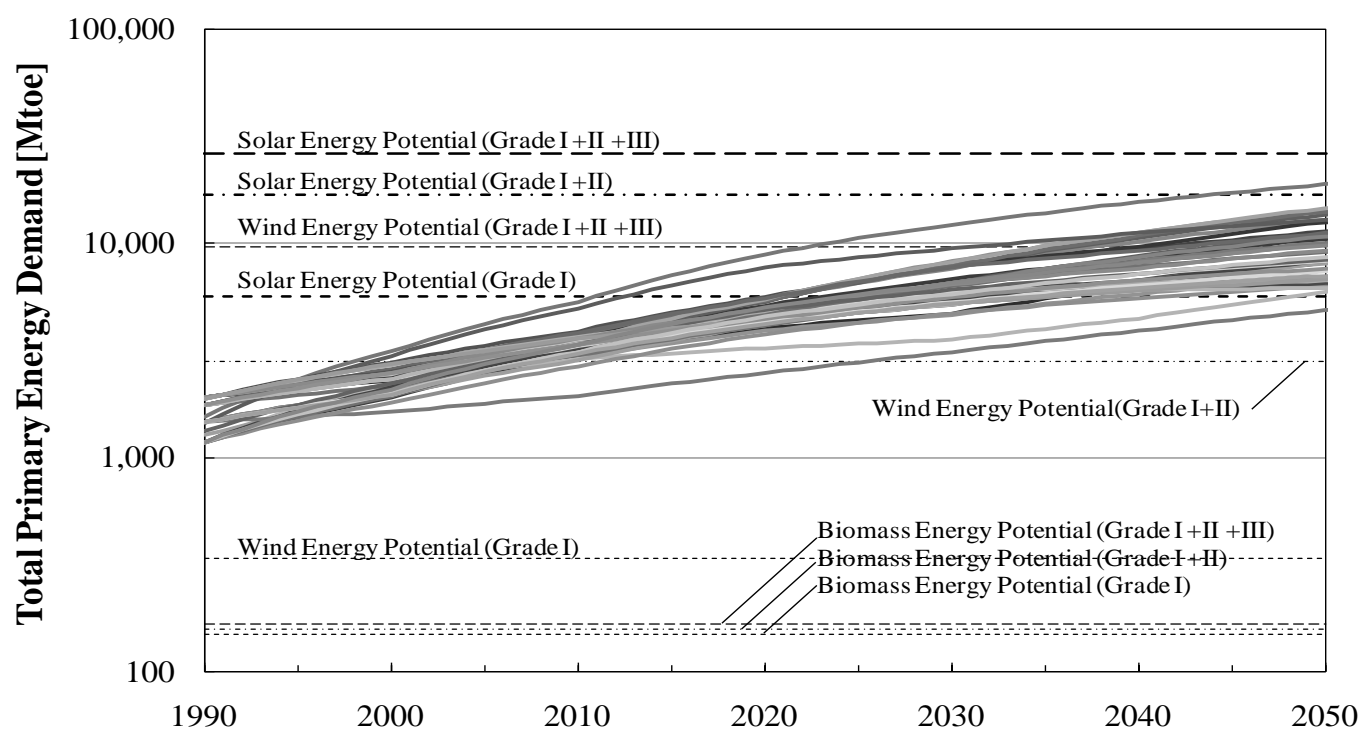

Fig. 1. Total primary energy forecast in published reports, and renewable energy potential

\subsubsection{Renewable energy contributions in each region}

Fig. 2 shows the outlook for primary energy supplies, fossil fuel supplies and renewable energies in three Asian regions: Japan, China and India. Each graph includes the maximum and minimum trends derived from the various reports collected and reviewed as part of this study. It can be seen that the renewable energy share is extremely small, overall. Fig. 2 also shows the calculation results obtained for physical and technical potentials (bold dashed lines). In the case of Japan and India, the solar energy potential (alone) exceeds the maximum predicted primary energy demand. On the other hand, China's energy growth is more rapid and larger than that of other Asian countries. Therefore, the renewable energy potential of China is not large enough to meet all of China's expected primary energy demand in the predicted maximum growth scenario. Renewable energy supply is effective even though fossil fuels will continue to dominate totally energy mixes for the foreseeable future.

\subsection{Economic potentials}

Fig. 3 shows the potential cost curve for three Asian regions: Japan, China and India. The horizontal axis (logarithmic scale) indicates the market potential. In the case of Japan, grade III solar energy shows most potential but has a high introduction cost. In contrast, the introduction cost of biomass energy is very low but the expected potential is small. In order to increase its share of renewable energy, Japan should, therefore, focus mainly on the installation of solar energy generation systems. In the case of China, the most potential is for grade II solar energy. The cost of grade III wind energy is more than $0.9 \mathrm{USD} / \mathrm{kWh}$ higher 
than other renewable resources. In India, grade I solar energy shows the most potential. Grade III wind energy also has a high cost, even in China and India. Consequently, solar energy should receive first priority for introduction and wind energy should be second. The potential for biomass energy is not as large, but its cost intensity is lower than either wind or solar power. Therefore, the immediate introduction of biomass energy systems could be an effective strategy in some Asian regions.
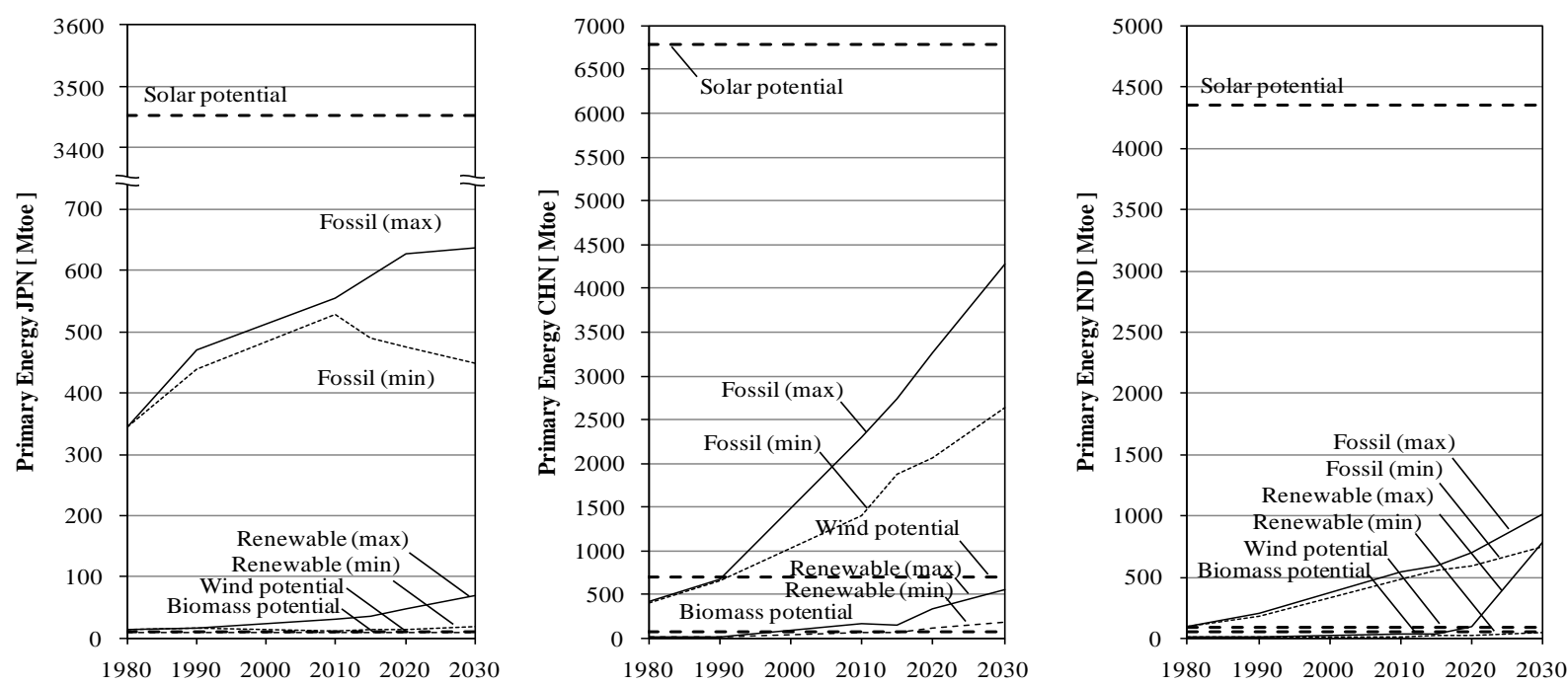

Fig. 2. Primary energy trends and renewable energy potentials in Japan (left), China (center), and India (right)
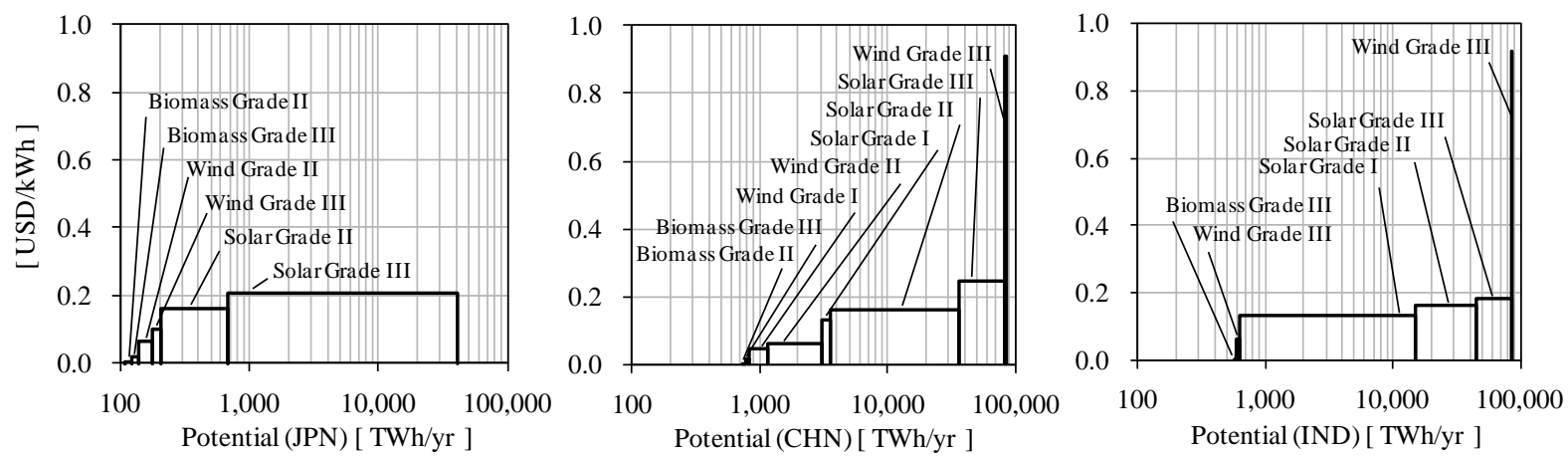

Fig. 3. Potential cost curves in Japan (left), China (center), and India (right)

\section{Conclusions}

Diversified analysis of potential renewable energy contributions to energy supply in Asian regions was carried out. As a result, estimates of renewable energy potential were refined, the socio-economic mechanisms associated with the introduction of renewable energy were calculated, and the relevant characteristics of each Asian country were analyzed. The results suggest that almost all Asian countries will continue to develop and that the demand for energy will grow drastically and rapidly. The results indicate that almost all Asian countries will continue to develop and that the demand for energy will grow. With the aspect from potential amount, renewable energy supply is effective even though fossil fuels will continue to dominate totally energy mixes fora the foreseeable future. In renewable energy supply, potential of solar is dominated and bears on wide implication compared with that of wind and biomass. To ensure the best possible results, further research should be carried out on the optimal schedule for the multi-phased introduction of renewable energy in long-term policy. 


\section{References}

[1] IPCC 2001a, Climate Change 2001 - IPCC Third Assessment Report, Working Group III: Mitigation, 2001

[2] Hofman, Y., de Jager, D., Molenbroek, E., Schilig, F., Voogt, M., 2002. The Potential of Solar Electricity to Reduce CO2 Emissions. Ecofys, Utrecht.

[3] Grubb, M.J., Meyer, N.I., 1993. Wind energy: resources, systems, and regional strategies. In: Johansson, T.B., Kelly, H., Reddy, A.K.N., Williams, R.H. (Eds.), Renewable Energy: Sources for Fuels and Electricity. Island Press, Washington, DC.

[4] Berndes, G., Hoogwijk, M., van den Broek, R., 2003. The contribution of biomass in the future global energy supply: a review of 17 studies. Biomass and Bioenergy 25 (1), 1-27.

[5] MODIS/Terra Land Cover Type Yearly L3 Global 1km SIN Grid, 2005: Land Processes Distributed Active Archive Center (LPDAAC), U.S. Geological Survey (USGS).

[6] GLOBE: The Global Land One-km Base Elevation 30-sec. DEM, National Geophysical Data Center (NGDC), NESDIS, NOAA, U.S. Department of Commerce.

[7] Hastings, D. A. and Dunbar, P. K., 1999: Global Land One-km Base Elevation (GLOBE) Digital Elevation Model Documentation, Boulder, Colorado, NOAA National Geophysical Data Center, Publication KGRD 34.

[8] GEBCO One Minute Grid - Version 1.02, 2006: General Bathymetric Chart of Oceans.

[9] World Wilderness Areas, 1993: the Sierra Club and World Bank, as integrated by UNEP/GRID.

[10] Insolation Incident On A Horizontal Surface (22-year Monthly \& Annual Average for July 1983 - June 2005), 2008: Surface meteorology and Solar Energy (SSE) Release 6.0 Data Set, Atmospheric Science Data Center, NASA Langley Research Center (LaRC).

[11]Wind Speed At 50m Above The Surface Of The Earth (10-year Monthly \& Annual Average for July 1983 - June 1993), 2005: Surface meteorology and Solar Energy (SSE) Release 5 Data Set, Atmospheric Science Data Center, NASA Langley Research Center.

[12]Bert J.M. de Vries, Detlef P. van Vuuren, and Monique M. Hoogwijk, Renewable energy sources: Their global potential for the first-half of the 21st century at a global level: An integrated approach, Energy Policy, 35, 2007, 2590-2610

[13]FAO, FAOSTAT 2001 CD-ROM, Rome, 2001

[14]IPCC 2001b, Special Report on Emissions Scenarios, 2001

[15] IEA, World Energy Outlook, 2008

[16]EUROPEAN COMMISION, World Energy Technology Outlook 2050, 2006

[17]ADB, Energy Outlook for Asia and the Pacific, 2009

[18] Greenpeace, Energy Revolution Sustainable Energy Global Energy Outlook, 2008

[19] Shell, Shell Energy Scenarios to 2050, 2008

[20] OECD, OECD Environmental Outlook to 2030, 2008 